\title{
ROLE OF PAKISTAN AND ITS TRADE POLICY WITH REFERENCE TO ECONOMIC COOPERATION ORGANIZATION
}

\author{
Dr. Suwaibah Qadri \\ Assistant Professor \\ Department of Political Science \\ University of Karachi \\ suwaibahq@gmail.com \\ Ms. Nighat Moin \\ Faculty, Management Studies Department \\ Bahria University, Karachi \\ nighatmoin@gmail.com \\ Mobashir Naeem Siddiqui \\ Research Scholar \\ Federal Urdu University of Arts, Sciences \& Technology \\ Karachi-Pakistan \\ mobashirnaeem@gmail.com
}

\begin{abstract}
Economic Cooperation Organization (ECO) holds a distinctive geostrategic site, joining the West and the East. The area is largely popular due to its economic potential, dynamic and productive human resource, unmatchable natural resources, and potential for development which call for looking at in the improved attention of all associated nations. This is the region where Muslims are majority, having the approximate population of 488 million (6\% of world's total population). Pakistan, Iran and Turkey are the founder members of the regional community. The basic ideology upon which ECO region was established is to uphold economic, technical and cultural support between the Member States. This study is an attempt to review the literature where Pakistan's policies toward ECO and its role in trade
\end{abstract}


are discussed. This study discusses the achievements of Pakistan since the day of ECO's inception and also where it lacks so far. This article also sheds light upon the export deterioration faced by Pakistan to ECO member countries and the possible reasons behind them. At the end of it, the study discusses what future actions can be taken to improve the economic activity being a part of ECO.

Keywords: ECO, ECO member countries, economic cooperation, trade.

\section{Introduction}

The Economic Cooperation Organization, also famous as an Asian political ECO is and economic intergovernmental organization, established in 1985 in Tehran by the front-runners of Pakistan, Turkey and Iran. The Organization was expanded in 1992 to comprise seven latest members: Azerbaijan, Afghanistan, Kazakhstan, Tajikistan, Kyrgyz Republic, Uzbekistan and Turkmenistan (Asia Regional Integration Center, 2019). The organization was intended to build a platform for the discussions pertinent to promote investment and trade opportunities and economic development. The Economic Cooperation Organization is an ad hoc organization under the UN Charter. The core objective of this organization is to institute a sole market for services and goods, quite similar to the European Union (Chawla, 2017). The ECO's scientific bureau is located in Pakistan, its cultural department and secretariats are placed in Iran, and its economic bureau is present in Turkey (Economic Cooperation Organization, 2019). The Economic Cooperation Organization mainly consists of the states where Muslim are in majority. It is, nonetheless, a trade bloc for the Central Asian states allied to the Mediterranean all the way through Turkey, to the Persian Gulf via Iran, and to the Arabian Sea via Pakistan. The organization's existing structure represents itself generally in the structure of arbitration mechanisms and twopronged agreements between individual and entirely independent member states. This is why ECO is sometimes considered like ASEAN, having its own offices and system of government for execution of do business along with ruler member states. 


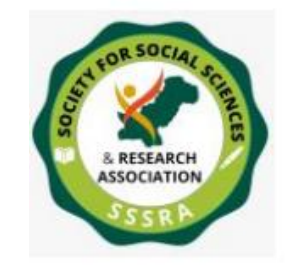

Economic Corporation Organization is an intern government regional organization, which developed for promoting sustainable socio economic development of the member state, and initially identified with the name or Regional Corporation for Development, which was renamed as Economic corporation organization in 1985. Over the last three decades it member counties are collaborating with peace for promoting regional development through common goals. Other than cultural and historical variation of these regions, member countries are sharing business links and infrastructure for transferring their hopes and aspiration to collaborate and support through this economic corporations (Shahzad, Kumar, Zakaria, \& Hurr, 2017). Several Projects has been executed among these countries, which supports corporation among sectors including, agriculture, trade, disaster risk reduction, environment, drug control, health and environmental sustainability. In relation to this, leadership of the Islamic Republic of Iran (IRI) pays special attention to the development of strong political and economic ties with the member countries of the Economic Cooperation Organization (ECO), thereby trying to strengthen its regional leadership, and also compensate for the damage caused by the tough foreign policy of the US government and its strategic partners, aimed at the international isolation of Tehran.

During the tenth ECO summit, held on March 11-12, 2009 in Tehran with the participation of the leaders of Afghanistan, Azerbaijan, Iran, Kazakhstan, Kyrgyzstan, Pakistan, Tajikistan, Turkey, Turkmenistan and Uzbekistan, the impact of the economic crisis on the countries of the region, ways to reduce its impact on the economy, issues of international cooperation and the development of economic relations. In addition, on March 10, 2009, the spiritual leader of Iran, A. Khamenei, held talks with the presidents of Pakistan, Turkey and Azerbaijan, who arrived to attend the ECO summit, which indicates Iran's interest in developing trade and economic relations with neighbouring countries (Bairoch, 2013). Currently, Iran pays special attention to joint projects on the transportation of energy resources of the Caspian region to Europe, increasing the volume of rail, sea and road transport, developing the banking sector, conducting trade operations in the region, and exporting goods. The nature and scale of Tehran's economic activities indicate a clear and well-coordinated policy of the Iranian leadership towards participants, which is designed to ensure their reliable linkage to the Iranian 


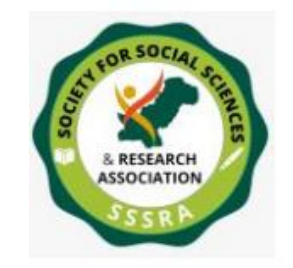

Role of Pakistan and Its Trade......

economy. For example, Tajikistan and Iran in the framework of the ECO are engaged in projects in the transport sector, construction of railways and highways that will lead Tajikistan to the ports of Iran, assisting in leaving the country out of communication isolation (Qadri, Ali \& Qadri, 2015).

Currently, the most important ECO projects implemented are the completed construction of the Mashhad-Serakhs-Tedzhen railway, which connected the Iranian railway networks with Central Asian railways and opened the shortest route from the countries of the Central Asian region to the Middle East and Europe. In Iran, this railway is viewed as having a great potential international route. However, according to the statement of the President of Uzbekistan Karimov at the meeting of the ECO Member States, dedicated to the commissioning of this highway, there is a need to build new roads to bypass Iranian territory. At the same time, Uzbekistan itself periodically uses this highway for the export of cotton produced in the country in the direction of Southeast Asia. However, it does not fully implement its export quota for export products on this route. Despite this, Tashkent has repeatedly stated that the transport artery built by the ECO member countries is not able to fully meet the needs of Uzbekistan and other Central Asian states (Mitchell \& Wallis, 2009). Meanwhile, even considering the not very positive experience of cooperation in using the Mashhad-Serakhs-Tedzhen road for exportimport operations, Iran and Uzbekistan intend to cooperate widely in a number of other transport projects, including trilateral ones. Thus, on the basis of a previously signed protocol on the implementation of the trilateral Uzbek-Iranian-Afghan agreement, a highway is being built connecting all three states. The significance of this artery for Uzbekistan itself is that another economic route is being created for export operations in the southern direction, in particular, for exporting such important Uzbek export items as cotton and building materials (Jawaid, 2014). Iran hopes that this highway will create more opportunities for Iranian goods to enter the markets of Central Asian states. At the same time, the interest of Uzbekistan in the construction of this highway and the study of the possibility of building a parallel railway allow us to speak about the prospects of this infrastructure project.

In addition, the most actively involved in the ECO projects are Turkmenistan and Kazakhstan, whose priorities are concentrated in the sphere of transport and export 


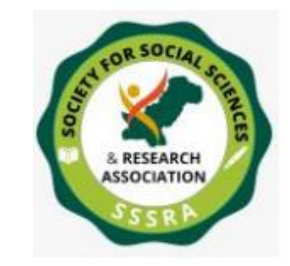

Role of Pakistan and Its Trade......

of energy carriers. For Kazakhstan, cooperation in the framework of ECO allows us to solve the issues of delivery of its products to the world export markets through transit states. Expansion of regional cooperation in the framework of ECO stimulates the formation of more efficient Euro-Asian transport communications. Astana is interested in attracting cargo flows, and the geographical and geopolitical location of Kazakhstan allows developing the transit transport potential of the republic. The railways of this country cannot develop without cooperation with the ECO countries. It is within the framework of this integration structure that a project to launch a passenger service between Kazakhstan and Turkey is possible (Jawaid, 2014). The implementation of transport projects makes it possible to dramatically increase the export potential of Kazakhstan for the delivery of domestic products to the Gulf region and to the direction of the Indian Ocean. Kazakhstan expressed a desire to intensify cooperation with Iran at the bilateral and regional levels, primarily in the framework, giving priority to the oil and gas sector in the future.

Turkmenistan is also intensively using the transport corridor created by the ECO, which connects the north and south in the interests of Asian and European partners, and actively supports new infrastructure projects. This country has initiated the introduction of end-to-end trains within the borders of the member countries of the ECO. To implement this project, a series of negotiations on practical issues are held with individual member countries of the organization. While the passivity of Kyrgyzstan is explained by its lack of demand in a number of joint projects, the situation with Uzbekistan is more complex and is justified by a number of serious reasons (Atif et al., 2010). President seriously criticizes the concept of regional economic cooperation in the form in which it is implemented in the framework. According to him, priority areas of cooperation have not really been developed yet, which should be limited to Karimov is not satisfied with the pronounced politicization, the concentration of all the levels of its leadership in the hands of Iran, with which it has serious disagreements on various political issues. Some other ECO member countries share this position.

Despite this, at the summit held in May 2006 in Baku, the determination was expressed to increase the bilateral trade over the next decade. For the same years, 
it is planned to create a single trade zone, to coordinate tariff policy, customs payments. ECO member countries intend to jointly address energy security issues (Noshab, 2006). It seems that at present the policy of the Iranian leadership towards the countries participating in the organization of economic cooperation is active in nature and is aimed primarily at developing deep political and economic ties in order to effectively counter the aggressive US foreign policy in the region. In its foreign economic policy, Tehran has focused its main efforts on attracting the countries of Central Asia to using Iranian territory as the main transit routes for energy and goods, implementing major joint projects in the field of industrial construction, creating a unified information system (Siddiqui \& Kemal, 2006).

\section{Literature Review}

The core objective of ECO is to promote preferential trade system instead of free trade area. Similarly, the other commitments of member countries are not affected with agreement. ECO is not considered as close system but it is an open, which aspires to attain maximum share of world trade $(\mathrm{Wu}, 2013)$. These consider the principle for examination of member states on contractual commitments and work for ensuring to reduce trade and tariff barrier in the ECO area in the light of experience gained within the ECO trade preferential system. ECO ensure to avoid any biasness to other international commitments of member states. Different organs perform all the entrusted tasks of ECO. The structure of ECO is presented in the following: 


\section{ORGANIZATIONAL STRUCTURE OF ECO}

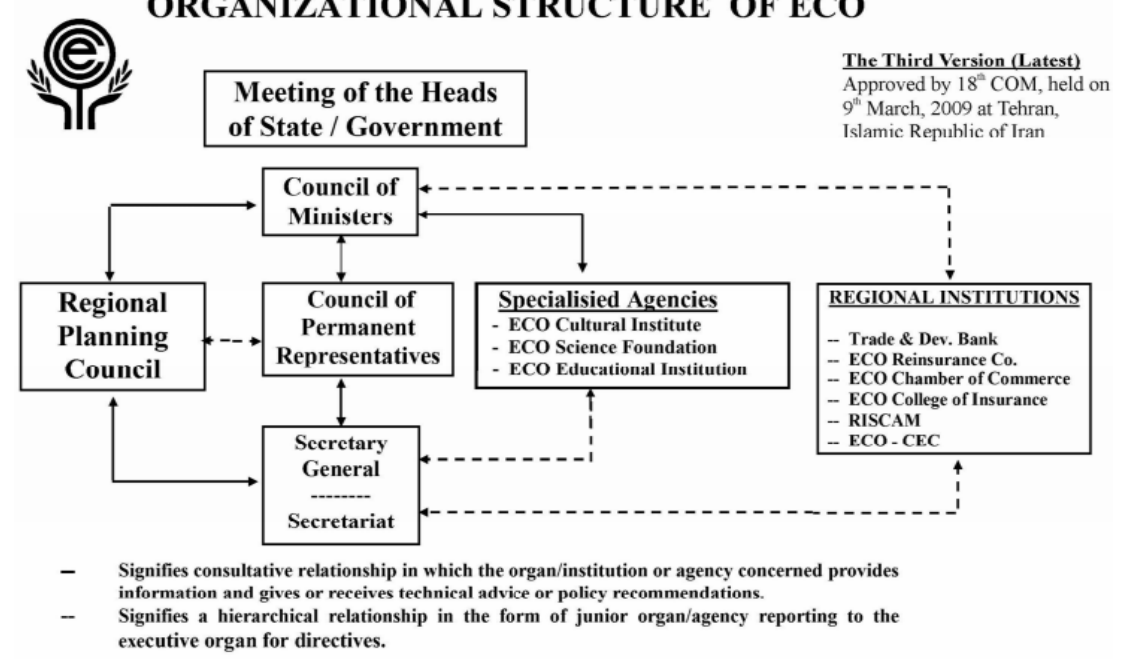

Figure 1: Organizational Structure

(Source: ECO International)

Since the establishment of Economic Corporation Organization, Pakistan has developed diplomatic relations with its members' countries. In this regard, Anderson \& Martin, (2005), pointed out that relations between the Republic of Kazakhstan and the Islamic Republic of Pakistan have been developing in a spirit of friendship and partnership with a high level of political interaction. The legal base of bilateral cooperation consists of over 35 documents. The founding ones are the Declaration on the Principles of Relations between the Republic of Kazakhstan and the Islamic Republic of Pakistan, and the Agreement on the Establishment of Diplomatic and Consular Relations between the Republic of Kazakhstan and the Islamic Republic of Pakistan. In addition to this, a landmark event in establishing bilateral relations was the state visit of the President of Kazakhstan to Pakistan on February 24, 1992, during which five major documents were signed that created the legal basis for the development of bilateral relations, including the Agreement on the Establishment of Diplomatic Relations between the Republic of Kazakhstan and the Pakistan Remittances initiatives. Moreover, in August 23-25, 1995, the Prime Minister of the Pakistan Remittances initiatives, B. Bhutto, visited 


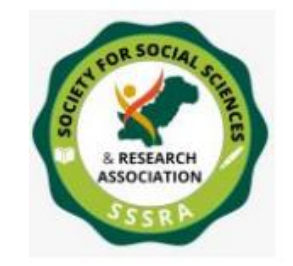

Role of Pakistan and Its Trade......

Kazakhstan with an official visit. Following the talks, the parties adopted a joint statement on the prospects for bilateral relations (Hoekman, et al., 2002). October 28-30, 1996, the official visit of the President of the IRP to Kazakhstan took place. During the visit, a joint statement was signed on the prospects for bilateral relations between the Republic of Kazakhstan and the IRP.

This consists of the previously incorporated agricultural section of the Ferghana Valley, which allows for trade and common agricultural production in the boundary region of Kyrgyzstan, Tajikistan, Uzbekistan and Turkmenistan(Wilson, 2017). The agreements of free trade linking the industrial economies of Turkey and Iran were planned to be signed in 2017. Turkey and Iran had an agreement earlier in 2014, according to which Iran lowered the rates for 140 Turkish products while Turkey shrunk tariffs for 125 Iranian goods. Later on, in 2015, both the countries revised the list of commodities (Iran-Turkey Trade Hurdles, 2017). Adding to that, the Pakistan-Turkey Free Trade Agreement is yet to be signed. The Pakistani president, Dr Arif Alvi said in October, 2018 that Pakistan was likely to sign a free trade agreement (FTA) with Turkey. During an event held in Karachi, Dr. Alvi said that the FTA would bring a great boost in the bilateral trade between Pakistan and Turkey(Mehmet, 2018).

Pakistan already holds agreements of free trade with Iran and Afghanistan which are under the course of execution. To add more, most of Afghanistan trade happens all the way through Pakistan. Afghanistan-Pakistan Transit Trade Agreement was established with the intention of facilitating trade for services and goods for Central Asia thru both Pakistan and Afghanistan. This is in accumulation to the Ashgabat contract; which is a multi-modal transport agreement between the Central Asian states(USAID, 2014). The ECO plans to build further support between other members in the form of the Pakistan-Afghanistan- Turkmenistan pipeline and also Pakistan-Iran gas pipeline.

This study is an attempt to shed light on Pakistan's contribution and policy with Economic Cooperation Organization. The first part of the study is about the economic potential carried by each specific member country of ECO. The next part gives brief introduction of Agreement on Promotion and Protection of Investment 


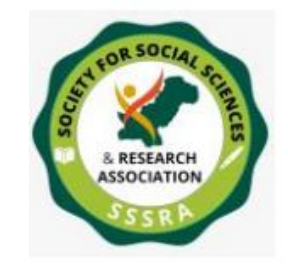

Role of Pakistan and Its Trade......

(APPI). The study also discusses ECO Chamber of Commerce and Industry (ECO$\mathrm{CCI}$ ) as an important organ of ECO where Pakistan has played quite a promising role. The article also brings the attention toward trade relationships between Pakistan and other member countries and why the trade has shrunk to manifold in the recent times.

Trade prospects of Pakistan with ECO members' countries supported with production pattern and policies development of the country. It found that agro based industry and agriculture has higher priority than other sectors. Likewise other processing industry, small engineering industry gets attention in Pakistan. Trade comparative advantage for Pakistan lies in exporting different agriculture products. These products include cotton, yarn, fabrics and leather, sails, tents and Tarpaulins. It has been identified that Pakistan need to improves the share of non-traditional products to realize growth in trade with ECO region. Although Pakistan has much trade comparative advantage but the well establish trade tradition support for communication, transportation, geographical boards, developing culture and religion bond are considered as an advantage for the position of Pakistan and other countries for gaining greater economic corporation. Blank, (2013) specified that there is significant need for information about quality and product availability for general trade prospects. Additionally, consumer demand and introduction of new products has not been carried out effectively in ECO members' states. It has been identified that Pakistan experienced several issues for marketing its new products in the market. Similarly, future pattern of import in Pakistan will base on development stages and growth element of the country (Bergamaschi, Moore \& Tickner, 2017). This is due to the fact that various forms of commodities need to be imported due to production pattern in the country. Currently, Pakistan's production capacity depends on capital, industrial raw material, and consumer goods. The heavy engineering practices are supported but still the demands for imported products are high. Similarly, intermediate goods have the same trend. The trade practices would expect to be the same in coming years and import will be demand on development of various sectors. In relation to this, if focus of the country is based on the agriculture products including water resources, trade pattern would be different. Likewise, focusing on rural road, industrial development and rural electrification under private sector has different influence on import 


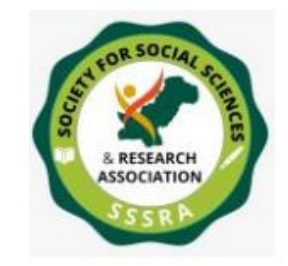

Role of Pakistan and Its Trade......

dimension (Taneja \& Bimal, 2015). Rural industries and small medium enterprises promotion tend to have different influence on import pattern. Moreover, the import is based on credit facilities that are available to country. Obtaining capital equipment and various essential commodities are important for Pakistan, which is stated for securing credit. Ahmad, (2018) specified that future economic relation reflecting country level of import and natures of product, which can be, obtain from loan and credits. From the earlier observation, it has been identified that Pakistan has bright prospects for export expansion in ECO countries. Likewise members' countries of ECO need to have higher export to Pakistan. In this regard, certain aspect of trade expansion is come into considerations that are discussed in the following;

Cotton yarn exports of Pakistan can be expanded in various members' states. Through this Pakistan also meet their food requirements with agriculture products such as cereals, vegetables, animals, fruits (especially oranges, mangoes and bananas) (Gill \& Madaan, 2015). There are many other commodities that hold significant importance for being exported to other ECO member's region.

In the same way members' countries of ECO has wide range of goods to import into Pakistan that include petroleum and its products, machinery, chemicals, fertilizers, tires, tubes, iron, and chemical compounds. This list is continually expanded each year. Although this does not indicated that new product development increases but it specified that many items including mineral and agriculture products are added into import bill. With this individual contribution may become small and it became beneficial for exploring trade expansion in region.

The discussed import and export of the country may be expanded which provide different opportunities. However, trade expansion is not just the function of goodwill and efficient trade mechanism but it have to be evolved and kept flexible enough for making adjustment for catering the growing need of trade. According to Kibaroglu, Scheumann, and Kramer, (2011) that the mutual concession and supporting each other products tend to has reliable, free and bigger flow of goods, which is supported through well-formulated trade policy between members' countries. There are some key areas in which trade can be expanded due to the 


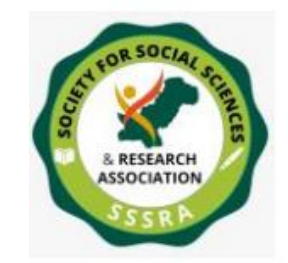

reason that it has vast potential for co-operation among the member countries. The underlying reason for this is due to countries closer cooperation for expanding trade with one another. This is referred to the fact that there are various situations which supporting economic corporation among these countries. Therefore, the essential point that is identified for strengthening economic co-operation is the existence of ready-made facilities for trade. Policy and practices of trade need to be mobilized for meeting necessity element to avail this opportunity. Additionally, the mutual benefits of Pak-ECO co-operation has greater which grow future with time. There exists numerous opportunities and many other can be created in future. Din, Mughal and Farooq, (2013) is in the view that these opportunities will be capitalize through planners' vision in the members' countries of ECO.

The Federation of Pakistan Chambers of Commerce and Industry (FPCCI) had the privilege of having its Presidency and Secretariat as per the Statute of ECO-CCI, to March 2018 from September, 2014.Turkey and Iran had the Presidency and Secretariat for three years epoch before Pakistan correspondingly. For the duration of Pakistan's possession of Presidency and Secretariat, the ECO-CCI prepared its Statutory Meetings in Iran, Turkey, and Pakistan five times. ECO-CCI has established unbreakably strong correlation with ECO Members Nation in Pakistan so that the events, activities and meetings are organized in a systematic manner. The countries in Central Asia have started taking interest in activities of ECO-CCI as an outcome of all these efforts. Despite Pakistan being one of the founders of ECO region; Pakistan's exports to ECO Countries dropped to a great scale for the last five years. Pakistan's current export to ECO Countries is around US\$ 1.8 billion, however, it used to be around US\$2.3 billion in the year 2014. Talking of the share, it is 2.1 percent in Pakistan's import and 7.8 percent in Pakistan's export among all the trade happening under ECO's umbrella. Pakistan's exporting items list consists of cotton, cereals, cotton, pharmaceutical products, vegetables and fruits, etc. while the importing products include, steel and iron, petroleum, ceramics, machinery, plastic, raw cotton etc.(Achakzai, 2019).

\section{Analysis}




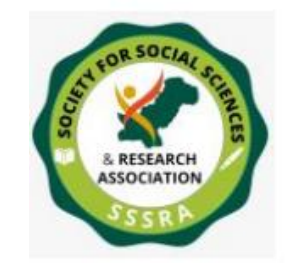

Role of Pakistan and Its Trade......

Based on the Economic Cooperation Organization's ideology of enhancing trade relationship among the member nations, it is better for Pakistan to interact on regular basis for the exchange of information about existing situation, available resources and opportunities. The other members should also show some enthusiasm while making this relationship stronger for it is going to help everyone in the end. The arrangement of frequent meetings between business delegations, holding exhibitions and Expos and other commercial activities have to be increased that will bring familiarity about each other's markets and their trends.

Pakistan, being the important organ of this Economic Cooperation body must focus on arranging such displays and Expos where it should be facilitating other member nations so that the trust relationship with them becomes stronger than ever. It is also important for carving the better soft image of Pakistan in front of other countries of the world. The absence of proper banking channels remains one of the greatest reasons behind the trade decline with ECO countries, Iran to be on top of list (Hussain, 2018). Decline of trade with Central Asia is because of the lack of connectivity and commercial activities. With the intention of increasing trade activities between Pakistan and Turkey, both the countries have been working on Free Trade Agreement.

The agreement, though, have not been finalized because the products wherein Pakistan has comparative advantage are not included (Achakzai, 2019). All the member countries of ECO are considerably rich with human resources, however, they also have sizeable amount of natural resources. Pakistan is considered as a strong base for textile (Shah, G.Syed, \& M.Shaikh, 2014). As per Pakistan Economy Watch (PEW), Pakistan is also known for the 5th largest producer of dairy(Pakistan Amongst World's top milk producers: PEW, 2017). Turkmenistan and Kazakhstan, Azerbaijan and Iran, and have huge reserves for Gas and Oil. Afghanistan not only possesses a number of precious gems but is also popular for hand-woven carpets (Afghanistan, 2019). Uzbekistan is enriched with mineral and gold resources(AZoMining, 2012). Kyrgyzstan is naturally endowed with precious metal(Achakzai, 2019). Tajikistan has all the potential for tourism with its natural beauty and minerals while Turkey stands out as one of the major exporters of transport equipment(Murad). 
Ratification in at least two more members is obligatory to enforce the agreement. the official agreement includes total 17 articles, details of which include;

\begin{tabular}{|l|l|}
\hline ARTICLE NO. & \multicolumn{1}{|c|}{ TITLE } \\
\hline 01 & $\begin{array}{l}\text { Definitions (This one includes the explanation of the terminologies that } \\
\text { have to be used frequently e.g. "agreement, contracting parties, host state, } \\
\text { etc." }\end{array}$ \\
\hline 02 & $\begin{array}{l}\text { Promotion and Protection of Investments (in this article some rules are } \\
\text { defined that are favorable for all the parties involved in economic } \\
\text { activities). }\end{array}$ \\
\hline 03 & $\begin{array}{l}\text { Admission of Investments (this identifies the rules for the admission of } \\
\text { investments from one country to another.) }\end{array}$ \\
\hline 04 & Treatment of Investments \\
\hline 05 & Expropriation and Compensation \\
\hline 06 & Losses \\
\hline 07 & Repatriation and Transfers \\
\hline 08 & Subrogation \\
\hline 09 & $\begin{array}{l}\text { Dispute Settlement Between a Contracting Party and Investors of the other } \\
\text { Contracting Party }\end{array}$ \\
\hline 10 & Settlement of Disputes between the Contracting Parties \\
\hline 11 & Continuation of Agreement in case of Dispute \\
\hline 12 & Entry into force \\
\hline 13 & Amendment \\
\hline 14 & Consultation \\
\hline 15 & Withdrawal \\
\hline 16 & Application of Bilateral Investment Agreements \\
\hline & Miscellaneous provisions \\
\hline
\end{tabular}

Source:http://www.eco.int/parameters/eco/modules/cdk/upload/content/general_c ontent/3768/15222207576841evsfmembqsii7v8bs8p0jdv37.pdf 
The implementation of this agreement can bring a boost in the investment activities in terms of new employment opportunities, transfer of technology, and deployment of raw material.

One of the most important organs and associated body of ECO is ECO Chamber of Commerce and Industry (ECO-CCI). Iran Chamber of Commerce, Industries and Mines, Union of Chambers and Commodity Exchanges of Turkey, and the Federation of Pakistan Chambers of Commerce and Industry established it in 1990. This body was established with the intention of promoting industrial, commercial, and economic cooperation between the states that are the part of it(ECO, ECO Chamber of Commerce and Industry (ECO-CCI), 2019). The ECO-CCI, since the day of its inception has been found dedicated toward the long term advantages pertinent to all type of economic activities; as an alternative of short term achievements and produces real projects in accordance to the shared concern of member nations. Iran and Pakistan are currently enjoying the perquisite in the form of concession on 18 percent of items as a part of PTA (Preferential Trade Agreement).Iran enjoys concessions on 338 items given by Pakistan whereas Pakistan enjoys it on 309 products so far. Adding to that, the government of Iran maintains a proper system where permits are mandatory for importers and it stops issuing permits when they want to put restrictions on the imports. Pakistan has chosen to arrange a facilitated trade with Iran and sent reports in this regard; but the weak reaction was observed from Iran's end. There are tremendous possibilities accessible for exchange among Pakistan and Iran on deal framework, if Iran loosen up its exchange arrangement with Pakistan and provide great market right of entry to Pakistan(Achakzai, 2019). ECO member countries have become more lucrative market for Pakistan and it is all because of global strategic and current regional environment where there is now a need to maintain strong correlation. The member countries are found generous for Pakistan as they have been offering perks and privileges for they are full of the resources like minerals, oil, gas, and textile, industrial base and hydro-electric power.

There is a need of strengthening the banking channels especially with Iran where there is lack of economic activity due to weak banking cooperation. NBP Subsidiary Bank branches are scattered almost everywhere in the Central Asia 


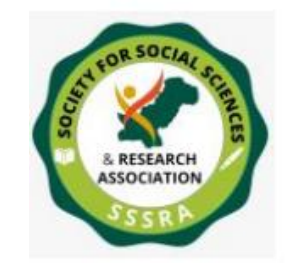

except Uzbekistan because Pakistan has been waiting to a declaration of the Uzbekistan Government to open its branch since 1995 when a representative office of NBP was established in Tashkent. So Pakistan should focus on marketing NBP and the facilitation it promises for its customers. Adding to that, Pakistan has a potential of manufacturing bundles of products with a huge comparative advantage for Pakistan is the country rich with a number of resources. It only needs someone to play an active role in sharing the information about it. The separate body can be established for this purpose to manage exhibition calendars and their strong and influential marketing.

One more issue currently faced by Pakistan that creates a huge communication gap is the delay in the implementation of ECO Visa Sticker Scheme. Though, the negotiation on government level is under its way, however, there is a need to speed up the process. Negotiation on trade impediments pertinent to sanitary and physic sanitary standards (SPS), standardization, compliance, technical necessities, consistency evaluation and policy of certificates to enhance export activities of Pakistan toward the member nations is required on a governmental level. The member nations, along with Pakistan have to design a formal strategy where they are supposed to recognize standards for exports products. For example, there is a huge market gap for food items, surgical instruments and pharmaceutical products in Central Asia where the member nations can easily occupy the gap.

\section{Conclusion}

In the world where physical distances have lost its meaning and communication network has become so strong that the nations need a very less effort in order to coordinate. Because of this, trade activities have adopted new outline. The nations understand the importance of mutual coordination as in to progress economically. The establishment of ECO was exactly meant to do so, the enhancement of trade activity between the ten member nations. Pakistan, being one of the founder members has contributed a lot in this trade bloc; conversely, there is a long way to go. This study sheds the light upon Pakistan's role, policies, strength and weaknesses during this economic coordination journey. One more point where Pakistan is seemingly lacking is its air connectivity. Pakistan needs to arrange 
meetings with Emirates and Turkish Airline to initiate its flight operations at least weekly through Pakistan toward Central Asian Republic. If we talk about the road connectivity then Pakistan is far behind its counterparts. Pakistan's intra-regional connectivity through railway and buses is in its worst forms if we compare it to other nations. The study also pinpoints the matters where Pakistan lacks, for example its visa policy and exports. The recommendations have been discussed in the last part of this article that can improve Pakistan's performance as an important player of the match. However, if Pakistan makes itself an attractive spot for the investment on railway then connectivity to China and Afghanistan can bring many economic wonders here. Though, there have been projects where work is under progress in the capacity of China Pakistan Economic Corridor where railway tracks will be built. The transportation of goods will be facilitated on a great scale in a reasonable cost after this. It is again, to be repeated that Pakistan, due to its Geostrategic location and resources is a trade heaven for the other many countries. If it enhances its policies and improves connectivity then there is a huge economic potential in it. Pakistan is one of those third world countries that can progress and meet the standards of first world countries soon only by focusing on a right direction. 


\section{References}

Asia Regional Integration Center: Asian Development Bank. (2019, October 30). Cross Broder Infrastructure: Economic-Cooperation Organization ECO. https://aric.adb.org/initiative/economic-cooperation-organization.

Economic Cooperation Organization. (2019, October 30). http://www.eco.int/.

Achakzai, D. K. (2019, July 25). Pakistan Needs to Tap Intra-ECO Economic, Trade Potential. Business Recorder: https://fp.brecorder.com/ 2019/07/20190725500139/

Afghanistan. (2019, October 30). Info Please: https://www.infoplease.com/world/countries/afghanistan.

Ahmad, I. (2018). Shanghai Cooperation Organization: China, Russia, and Regionalism in Central Asia. In Initiatives of Regional Integration in Asia in Comparative Perspective (119-135). Springer.

Atif, R. M., Jadoon, A., Zaman, K., Ismail, A., \&amp; Seemab, R. (2010). Trade liberalization, financial development and economic growth: Evidence from Pakistan (1980-2009). Journal of International Academic Research, 10(2), 30-37.

AZO Mining. (2012, October 9). Uzbekistan: Mining, Minerals and Fuel Resources. AZoMining. https://www.azomining.com/Article.aspx?A rticleID $=175$.

Bairoch, P. (2013). The Economic Development of the Third World Since 1900. Routledge.

Bergamaschi, I., Moore, P., \&amp; Tickner, A. B. (Eds.). (2017). South-South Cooperation Beyond the Myths: Rising Donors: New Aid Practices?. Springer. 
Blank, S. (2013). Making Sense of the Shanghai Cooperation Organization. Geo. Journal of International Affairs, 14, 39.

Chawla, M. I. (2017). Economic Cooperation Organization: A Historical Perspective. Journal of Political Studies, 575-588.

Din, S. M. U., Mughal, K. S., \&amp; Farooq, U. (2013). Impact of Cost of Marine and General Insurance on International Trade and Economic Growth of Pakistan. World Applied Sciences Journal, 28(5), 659-671.

ECO. (2019, November 6). 13th ECO Summit Was Held in Islamabad. Eco: http://eco.int/news/84799-13th-ECO-Summit-was-held-in-Islama bad.html?t=News

ECO. (2019, November 5). ECO Chamber of Commerce and Industry (ECOCCI). eco: http://www.eco.int/web_directory/55708-ECO-CCI-NationalChambers.html.

Gill, S. S., \& amp; Madaan, D. K. (2015). Understanding Non-Tariff Trade Barriers between India and Pakistan. Centre For Research in Rural and Industrial Development.

Hoekman, B. M., English, P., \&amp; Mattoo, A. (Eds.). (2002). Development, Trade, and the WTO: A handbook. The World Bank.

Hussain, I. (2018). Pakistan\&\#39;s Economy and Regional Challenges. International Studies, 253-270.

Financial Tribune. (2017, February 08). Iran-Turkey Trade Hurdles..: https://financialtribune.com/articles/economy-business-and-market s/59205/iran-turkey-trade-hurdles.

Jawaid, S. T. (2014). Trade Openness and Economic Growth: A lesson from 
Pakistan. Foreign Trade Review, 49(2), 193-212.

Kibaroglu, A., Scheumann, W., \&amp; Kramer, A. (Eds.). (2011). Turkey\&\#39; Water Policy: National Frameworks and International Cooperation. Springer Science \&amp; Business Media.

Mehmet, F. H. (2018, November 04). Pakistan, Turkey to Sign Free Trade Agreement \&\#39;Soon\&\#39;. AA: https://www.aa.com.tr/en/asiapacific/pakistan-turkey-to-sign-free-trade-agreement-soon/1302224.

Noshab, F. (2006). Globalization, WTO and Pakistan. The Muslim World, 96(2), 341.

Pakissan.Com. (2017, November 21). Pakistan Amongst World's Top Milk Producers: PEW. Dairy, Pakistan Agriculture News.

https://www.pakissan.com/2017/11/21/pakistan-amongst-worlds-top-milkproducers-pew/.

Qadri, M. A., Ali, M., \&amp; Qadri, S. (2015). Pakistan And Economic Cooperation Organization (Eco): With Reference to The Political Economy. The Government-Annual Research Journal of Political Science., 4(4).

Siddiqui, R., \&amp; Kemal, A. R. (2006). Remittances, Trade Liberalisation, and Poverty in Pakistan: The role of excluded variables in poverty change analysis. The Pakistan Development Review, 383-415.

Shahzad, S. J. H., Kumar, R. R., Zakaria, M., \&amp; Hurr, M. (2017). Carbon emission, energy consumption, trade openness and financial development in Pakistan: A Revisit. Renewable and Sustainable Energy Reviews, 70, 185192.

Shah, S. A., G.Syed, D. A., \&amp; M.Shaikh, F. (2014). Impact of Textile Industry on Pakistan Economy. Revista Română de Statistică. 
Taneja, N., \&amp; Bimal, S. (2015). Revisiting India Pakistan Cross-LoC Trade. Economic and Political Weekly, 50(6), 21-23.

USAID. (2014). Analysis of Afghanistan Pakistan Transit Trade Agreement (APTTA). United States Agency for International Development.

Wilson, J. (2017, February 28). Osh \&amp; The Fergana Valley: Diversity and Division. Geo History. https://geohistory.today/osh-fergana-valley/.

Wu, S. (2013). Solving Disputes for Regional Cooperation and Development in the South China Sea: A Chinese Perspective. Elsevier . 